\title{
Applying Narative Leraning to Improve Students Creativity of Drawing Illustration
}

\author{
Taswadi* \\ Departemen Pendidikan Seni Rupa \\ Universitas Pendidikan Indonesia \\ Bandung, Indonesia \\ *taswadi@upi.edu
}

\begin{abstract}
The obligation of the lecturers to draw to improve the ability of creativity, because the level of creativity determines the level of variation in the shape of the drawings it makes. Based on several studies of the results of the form of images, in drawing illustrations it was concluded that the results of the drawing of the students looked monotonous and stereotyped (uniform). The purpose of this study is to improve the ability of creativity so that the illustrations they make are varied. To achieve these objectives researchers apply narrative learning. The research method that the researchers used was action research by taking a sample of class students of the Faculty of Fine Arts Education Study Program, Faculty of Arts and Design Education, Universitas Pendidikan Indonesia. of the Indonesian Education University. The first learning uses conventional learning, the second learning with narrative learning. The results of the first learning picture with the second are compared based on the picture elements. After comparing the results of the learning picture using narrative learning, the elements of the picture are more varied.
\end{abstract} picture

Keywords-narrative learning, drawing illustrations, variative

\section{INTRODUCTION}

Based on the results of previous research on drawing learning, it can be concluded that the average image results are monotonous [1-3]. The same thing happened in other countries, namely in Estonia [4] which resulted in the study that most of the monotonous image results. A similar thing happened in America [5]. Monotonous image as an indication that the image maker is less creative. The same thing happened to students majoring in Fine Arts Education in Indonesia, so the writer tries to find a solution, namely by applying narrative learning. The difference between the author's research with the research of other researchers, including: As in the introduction based on the results of previous research on drawing learning produces a conclusion drawing of students on average monotonous. Some of these studies try to overcome them by changing learning, which originally applied visual aids with monotonous and uniform images, changed with learning not using visual media, and research with analogous learning both produce more varied images. Applying discovery learning models to produce creative images [6], applying discovery inquiry learning also in order to improve the ability to draw creativity [7]. Research drawing on students conducted by the predecessor researchers. For example [8] produces a form of learning in drawing puppets [9] produces a form of learning to draw, [10] produces a form of learning to draw to increase creativity. The same thing happened to some students in other countries. In the State of Estonia [11] Initially applying conventional drawing learning tends to be monotonous. Vahter in his research conducted action research by applying drawing learning through appreciation media to discuss contemporary art. The results of this study conclude that learning through appreciation of contemporary art can produce more varied student images Other studies [12] (in the United States in order to enhance the ability of creativity by using a play approach. All researchers try to improve their creativity ability in various ways so that the images of their students are varied. The difference between the author's research and that of the previous researchers is that no previous research has examined the experience of individuals as ideas in work, through narrative learning students are led to draw based on their own experiences, why the authors examine experience as ideas in work, because individual experiences are diverse. This is a factor in determining ideas in drawing. Based on the diversity of experiences can affect the visualization of the form of images. The advantage of this research is that it can accelerate the determination of ideas in drawing so that the process of making drawings is more effective. Another advantage is the results of images created with narrative learning produce varied forms of images.

\section{LITERATURE REVIEW}

\section{A. Learning to Draw Illustrations}

Learning is the process of interaction between students, teachers, and the environment to achieve certain abilities $[13,14]$. In learning requires a learning approach. In addition to approaches in learning fine arts, active, innovative, creative and pleasing learning is needed.

Observing the opinions above, it can be emphasized that the learning model that can create active, innovative, creative, and fun learners is very important so that it is appropriate to be 
used in learning. In addition to the right model, learning requires methods. There are several methods in learning Fine Arts that can develop creativity and skills, namely: the free expression method, and to hone skills using the drill method.

Drawing illustrations in his position as part of the subject of fine arts education courses that focus on skill or expertise, so the course draws illustrations to equip students for experts in the field of fine arts.

\section{B. Drawing Illustrations}

Drawing illustrations is the ability to construct experiences that have settled in the heart and mind, then combined with new experiences that they receive, and organized into new forms of construction [15], in the form of creative twodimensional visual works. Student experience in drawing obtained at elementary and secondary levels, and other previous experiences as experiences that will be assimilated and accommodated in the ability to draw in lectures, thus forming new experiences that are more mature. Experience drawing techniques such as how to choose a theme, determine materials, media, and techniques, experience drawing practices such as how to make lines, areas, textures, colors, shapes, and compositions, obtained when education in elementary and secondary, as an experience capital for combined with experiences received in college so that they are constructed into new abilities [16].

The practice of drawing the illustration itself as already mentioned above, is a practice of arranging and constructing the elements of the picture, such as line elements, areas, colors, textures, shapes, compositions, themes, into a unity of new visual forms [17].

\section{Learning Theories of Contructivism}

The theory of constructivism learning as a reference because drawing essentially organizes prior knowledge and experience with the knowledge and experience received when learning at that time, is constructed into new knowledge and experience in visual form. The theory of learning according to understanding constructivism is a process of assimilating and linking the experiences or lessons learned with the understanding they already have, so that their knowledge can be developed. Constructivism is defined as generative learning, which is the act of creating something meaningful from what is learned. One of the figures who influenced the constructivist theory was Piaget's theory of cognition, which argues that since childhood the individual already has a cognitive structure called a scheme (schema). The schemata will determine how it will respond to the physical environment. Schemata can appear in the form of clear behavior or hidden or hidden (in the mind). The scheme will change and develop through the learning process. Schemes are the potential to act in certain ways. Schema in the plural (schemata) as an element in the cognitive structure of an organism, the scheme is formed because of experience. The scheme will develop through the process of assimilation and accommodation. Assimilation (assimilation) is the process of responding to the environment in accordance with the organism's cognitive structure. Cognitive structure is the number of organism's schemata over a certain period of time. Accommodation is the process of modifying cognitive structures. In the accommodation process there is an equilibration process. Piaget assumes that all organisms have an innate tendency to create a harmonious relationship between themselves and their environment, for that optimal adaptation is needed, then equilibration is needed. Equilibration is a continuous push towards balance. The growth process of the organism's intellectual growth through the mechanism of assimilation and accommodation and is driven by equilibration [18].

Drawing illustrations is drawing thoughts and feelings to be communicated to others. This is consistent with the opinion that writes that drawing illustrations as a form of communication to pour feelings and thoughts towards something in the form of two-dimensional fields in the form of images, so that people who see it know what they are drawing [19].

\section{METHODS}

This study uses a qualitative approach with action research research methods. In its implementation, the researcher directly conducted teaching practice in the classroom [20]. The population for research studies was class A students totaling 40 people in the Fine Arts Education Study Program. Research location in the Department of Fine Arts, Faculty of Arts and design, Universitas Pendidikan Indonesia. Research time In the full semester of the 2019/2020 academic year, from February 2020 to December 2020.

The research uses several types of research instruments. Researchers developed several instruments with the assistance of relevant experts and adapted several existing instruments. The types of instruments developed in this study include: 1) Instrument Interview Guidelines; The form of interviews conducted by researchers against students, the implementation of lectures to draw illustrations before applying narrative learning. The purpose of the interview is to find out the students' responses to the lectures to draw illustrations. 2) Questionnaire; This questionnaire is in the form of questions and alternative answers that have been developed by researchers. Respondents only need to put a checklist on one alternative answer that is considered appropriate. This questionnaire is to take data on student responses to illustrative drawing courses, after lecturing with narrative learning. 3) Observation Instrument for Lecture Implementation; The instrument for analyzing the implementation of lectures is to determine the quality level of lecturing. This instrument was developed by means of adapting the instrument that had been developed by the Department of Fine Arts Education. The function of this instrument is to find out whether the lecturer implementing the narrative learning is in accordance with the steps of narrative learning or not, and to know the behavior of students while attending lectures. 4) Instrument for Drawing Illustration Practices; This illustration drawing practice assessment instrument was developed based on input from 
experts learning to draw illustrations and adapt the practice assessment format based on the 2013 Curriculum. The function of this instrument is to determine the level of variation in the results of the drawings. Research Procedure with 3 stages, namely the first preliminary study with literature study activities, observation, questionnaires, and interviews, from the preliminary study continued with the development of learning forms. The second stage is the formulation of the learning model based on the results of the preliminary study. The third stage is testing the form of learning results of the development produced in the preliminary study with action research methods. The lecture practice is carried out on one class with narrative learning.

The stages that have been carried out above, the first is a preliminary study with a qualitative descriptive approach to explore concepts through literature study and field surveys to determine the objective conditions of the object under study. The results of library studies and field surveys as input for the development of narrative learning forms. The second stage is to formulate a form of narrative learning based on models of literature study results and input from learning experts. The third stage of conducting lectures in class is by applying narrative learning.

\section{RESULTS AND DISCUSSION}

\section{A. Implementation and Preliminary Research Results}

During the preliminary research, interviews were conducted with students about the implementation of the illustration drawing lectures. The results of interviews with students include; perception of learning to draw illustrations, the purpose of drawing illustrations, responses to lecturers in teaching, and lecturing methods. Based on interviews with their perceptions of drawing illustrations on average they answer as an important subject, because they can practice the visualization skills of a particular story or scene, which is needed by visual art creators. The response to the purpose of taking the illustration drawing course is to improve visualization of ideas in the visual form. Regarding responses to lecturers supporting their courses, they generally liked. Their response to the lecture methods conducted by the lecturers was quite good, only they had difficulty at the beginning of carrying out the practice of drawing, sometimes it was difficult to find ideas for drawing. The results of conducting interviews with students can be observed in table 1 below:
TABLE I. RESULTS OF INTERVIEWS WITH STUDENTS

\begin{tabular}{|l|l|}
\hline \multicolumn{1}{|c|}{ Asked Aspect } & \multicolumn{1}{|c|}{ Answer of Students } \\
\hline $\begin{array}{l}\text { Perception of learning to } \\
\text { draw illustrations }\end{array}$ & $\begin{array}{l}\text { The course drawing illustration is very } \\
\text { important for students }\end{array}$ \\
\hline $\begin{array}{l}\text { The purpose of drawing } \\
\text { illustrations }\end{array}$ & $\begin{array}{l}\text { The purpose of following the illustration } \\
\text { drawing course is to improve the skills to } \\
\text { visualize ideas in visual form }\end{array}$ \\
\hline $\begin{array}{l}\text { Responses to lecturers } \\
\text { in teaching }\end{array}$ & $\begin{array}{l}\text { On average they like the way the lecturer } \\
\text { teaches }\end{array}$ \\
\hline $\begin{array}{l}\text { The method used by the } \\
\text { lecturer }\end{array}$ & $\begin{array}{l}\text { The lecture method used by lecturers is quite } \\
\text { good, only they have difficulty at the } \\
\text { beginning of implementing drawing practice, } \\
\text { sometimes it is difficult to find ideas for } \\
\text { drawing. }\end{array}$ \\
\hline
\end{tabular}

Based on the results of interviews with the students of the four questions, all answered positively, but there was an answer to the last question which was about the teaching method of lecturers who were answered with like, but there were complaints that it was difficult to look for ideas when going to start drawing. It means that this problem causes the students to end up bluntly looking for new ideas in the work, so that sometimes it causes the work made to be less varied and less innovative, because creativity is hampered because of experiencing a deadlock in the discovery of new ideas. Based on these problems, researchers look for solutions by making learning that can enrich ideas in the work. Based on several sources explaining among them [21] each individual has a diverse experience. A person's experience can be used as ideas in work [22] So that experiences can be used as ideas of work. Works that are based on diverse experiences produce diverse works as well. The diversity of works appears from the diversity of visualized object shapes, and image-forming structures, such as image colors, textures, and compositions. [23] For this reason researchers create learning forms that can lead students to work based on their own experiences. One form of learning that researchers arrange is narrative learning.

\section{B. Results of Documentation Study Results of Lecture Implementation}

1) Documentation study results: Referring to the results of interviews and documentation studies about the basic theories or concepts collected through library research, the researchers then drafted a narrative learning product to be developed. After the initial draft was made, it was then reviewed in a meeting with experts in curriculum and learning, fine arts education, and several senior lecturers in Fine Arts Education. Based on the input in the meeting the initial draft form was then refined and the results duplicated according to the needs in making narrative learning forms. Forms of Narrative Learning that researchers arrange as follows figure 1: 
1. The lecturer tells the most memorable experience

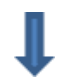

2. Students listen to the lecturer story

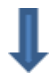

3. The lecturer assigns students to share their experiences

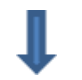

4. The lecturer assigns students to draw on their own experiences.

Fig. 1. Narrative defending scheme.

2) Results of narrative learning implementation: Narrative Learning Process Results; After the form of narrative learning is completed, it is then put into practice in lectures. Implementation of lectures by assigning lecturers to draw illustrations to implement it in the class he used to teach.

The course of the learning process as follows; When the lecturer in the course enters the classroom with the researcher, the students are already in their respective seats. Furthermore, the lecturer invited the researcher to sit at the back of the table provided. The lecturer immediately told me about his experience while traveling from home to campus. Surprising things, funny, traffic jams, and the beauty of the city along the way told. In the end of the story the lecturer tells one of his experiences that is most strongly recalled in his mind, because the experience made him feel scared and worried, that is when he saw a woman dropping a child in an elementary school uniform riding behind with a motorcycle, the child's shoes were pillion fallen, then thrashed to ask to stop the speed of the motor and go down to get the shoes that fell. So that the woman immediately stopped the motorbike suddenly, and the motor slipped, until the woman and child who were pillion fell. Immediately the traffic became a total traffic jam, because some motorcyclists stopped, and some of them who got off the motorbike immediately helped the woman and child. "Including me who was behind the woman and the fallen child was behind them," he said. Furthermore, the lecturer continues to start drawing illustrations, with questions and answers. In one of the questions the lecturer asked the most memorable experiences experienced by students when leaving for campus. Then explain that the most memorable experience can be made into ideas in drawing illustrations. Furthermore, the lecturer assigns students to draw illustrations with the theme "memorable experiences when leaving for campus". Students seemed to start preparing the media and drawing tools then they looked thoughtful, while starting to draw. During the process of implementing learning by implementing narrative learning, researchers take notes with the observation sheets that have been provided. The results of observations appear in table 2 below:

TABLE II. OBSERVATION RESUlTS OF THE APPLICATION OF NARRATIVE LEARNING PROCESS IN DRAWING ILLUSTRATIONS

\begin{tabular}{|l|l|}
\hline \multicolumn{1}{|c|}{ That Aspect Is Observed } & \multicolumn{1}{|c|}{ Observation result } \\
\hline $\begin{array}{l}\text { 1. Lecturer in the implementation } \\
\text { of narrative learning }\end{array}$ & $\begin{array}{l}\text { Lecturers in implementing narrative } \\
\text { learning are in accordance with the } \\
\text { stages, namely beginning with } \\
\text { personal experience, then holding } \\
\text { questions and answers about each } \\
\text { student's experience, and continuing } \\
\text { to assign the practice of drawing } \\
\text { illustrations with the theme } \\
\text { "Experiences when traveling to } \\
\text { campus". }\end{array}$ \\
\hline $\begin{array}{l}\text { 2. The attitude of students during } \\
\text { the lecture process }\end{array}$ & $\begin{array}{l}\text { lecture process by applying narrative } \\
\text { learning, seemed focused and } \\
\text { enthusiastic. }\end{array}$ \\
\hline
\end{tabular}

From the results of observations about the course of the implementation of narrative learning, the implementing lecturer appears to have carried out the defensive steps according to the planned scenario. The students' attitude during the lecture process seemed focused, enthusiastic, and active. This is an indication that the stages of the narrative learning process carried out are going well. One step an educator has done well in learning practices, is expected to produce good learning outcomes, as explained by [24].

3) The results of the evaluation of narrative learning work: After the lecture process is finished, the work of student drawings is collected and assessed. The results of this assessment will be averaged as a grade average, to know the success or failure of learning. Because one of the experts said that the success of learning can be known from the value of learning outcomes [25]. To find out the results of student work can be observed in table 3 below:

TABLE III. Summary of PRACTICE VALUes Results of LeCtures

\begin{tabular}{llllllllll}
\hline $\mathbf{N a}$ & $\mathbf{N a}$ & $\mathbf{N a}$ & $\mathbf{N a}$ & $\mathbf{N a}$ & $\mathbf{N a}$ & $\mathbf{N a}$ & $\mathbf{N a}$ & $\begin{array}{c}\text { Na } \\
\mathbf{m}-\end{array}$ & $\begin{array}{l}\text { Na } \\
\mathbf{m}-\end{array}$ \\
$\mathbf{m}-$ & $\begin{array}{c}\mathbf{m}- \\
\mathbf{b e}\end{array}$ & $\begin{array}{c}\mathbf{m}- \\
\mathbf{b e}\end{array}$ & $\begin{array}{c}\mathbf{m}- \\
\mathbf{b e}\end{array}$ & $\begin{array}{c}\mathbf{m}- \\
\mathbf{b e}\end{array}$ & $\begin{array}{c}\mathbf{m}- \\
\mathbf{b e}\end{array}$ & $\begin{array}{c}\mathbf{m}- \\
\mathbf{b e}\end{array}$ & $\begin{array}{c}\mathbf{m}- \\
\mathbf{b e}\end{array}$ & $\begin{array}{c}\mathbf{b e} \\
\mathbf{b e}\end{array}$ \\
$\mathbf{1}$ & $\mathbf{2}$ & $\mathbf{3}$ & $\mathbf{4}$ & $\mathbf{5}$ & $\mathbf{6}$ & $\mathbf{7}$ & $\mathbf{8}$ & $\mathbf{9}$ & $\mathbf{1 0}$ \\
\hline Sc & Sc & Scor & Scor & Scor & Scor & Scor & Scor & Sc & Sc \\
ore & ore & e 4 & e 4 & e 4 & e 4 & e & e 4 & ore & ore \\
4 & 3 & & & & & 3 & & 4 & 4 \\
\hline
\end{tabular}

Observing the results of the recapitulation of student practice scores from 10 students sorted from number $1,2,3,4$, $5,7,8,9$, 10, with the values obtained: $4,3,4,4,4,4,3,4,4$, 4. The average value is the total value of all works assessed divided by the number of works assessed, which is $4+3+4+$ $4+4+4+3+4+4+4=38: 10=3,8$ or A-. So the average grade is 3.8 or A-. A value of 3.8 or A- is a very good value 
[26]. Thus the learning outcomes using narrative learning produce good results

\section{CONCLUSION}

After completing the research it can be concluded that narrative learning is appropriate to accelerate the process of students in determining themes in drawing. Because with narrative learning students are led to remember their own experiences, so it is easy to pour in the form of images. Narrative learning can also make students work according to personal experiences that are different from the experiences of others, this causes various forms of experience to affect the diversity of images. The diversity of forms of this image as one of the varied images. The form of varied images as a characteristic of creative creators. So it can be concluded that the application of the application of narrative learning by using the Workshop method can increase student creativity. The level of awareness and concern in maintaining cleanliness, natural beauty, and declining mutual cooperation culture and discipline in work can be regained through activities that have functions for the public interest. The assistance activities paint trash cans as one of the activities that can increase awareness of attitudes to care about the cleanliness and beauty of the environment in public places.

\section{ACKNOWLEDGMENT}

The authors would like to thank Department of Fine Arts, Faculty of Arts and Design Education, and the Research and Community Service Institute, Universitas Pendidikan Indonesia who have provided financial assistance, so that this research can be completed.

\section{REFERENCES}

[1] S. Faizah, Upaya Meningkatkan Kreatifitas Menggambar motif Batik dengan Metode Discovery Inquiry. (Penelitian Tindakan Kelas pada Siswa Kelas VIII A SMPN 2 Simo Boyolali). Universitas Sebelas Maret.Indonesia. 2013.

[2] Taswadi, "Painting Waste with Communities on the Edge of Citarum River Indonesia" Proseding Advances in Social Science, Education and Humanities Research, volume 419 2nd International Conference on Arts and Design Education (ICADE 2019). Atlatis Press. 2019.

[3] E. Vahter, "Looking for a Possible Framework to Teach Contemporary Art in Primary School," The International Journal of Art \& Design Education, vol.35. pp. 35:517. 2016.

[4] P. Yudha, Sigit, Pengaruh Model Pembelajaran Discovery Learning terhadap Motivasi Belajar pada Mata Pelajaran Menggambar dengan Perangkat Lunak. Bandung: Universitas Pendidikan Indonesia, 2015
[5] C.S. Nielsen, C, G.M. Samuel, L. Wilson, \& K.A.Vedel, Seeing' and 'Being Seen': An Embodied and Culturally Sensitive Arts-Integrated Pedagogy Creating Enriched Conditions for Learning in Multi-Cultura Schools, International Journal of Education \& the Arts. Vol. 21. 2. 2020.

[6] G. Rosarina, A. Sudin, A. Sujana, "Penerapan Model Pembelajaran Discovery Learning untuk Meningkatkan Hasil Belajar Siswa pada Materi Perubahan wujud Benda,” Jurnal Pena Ilmiah: Vol. 1, No. 1 hal. 371-380. 2016

[7] H. Simons and D. Skoreyko, "The Art of Teaching Creativity. "Jounal Art Education. 2016.

[8] P. Yudha, Sigit, Pengaruh Model Pembelajaran Discovery Learning terhadap Motivasi Belajar pada Mata Pelajaran Menggambar dengan Perangkat Lunak. Bandung: Universitas Pendidikan Indonesia, 2015.

[9] B. Nurgiyantoro, "Wayang Pengembangan Karakter Bangsa," Jurnal Pendidikan Karakter, Tahun I, Nomor 1. Pp. 1-17, 2011.

[10] A. Jaya, Wayang 1-2. Fakultas Seni Rupa dan desain PS. Kria Produk. ISI Denpasar. Bali. 2013.

[11] M. Wiyono, Analisis Kemampuan Menggambar Ilustrasi Manusia Pada Matakuliah Gambar DiPapan Tulis Mahasiswa. Jurusan Pendidikan Seni Rupa FBS UNIMED. I, 2012.

[12] M. Wiyono, Analisis Kemampuan Menggambar Ilustrasi Manusia Pada Matakuliah Gambar di Papan Tulis Mahasiswa Jurusan Pendidikan Seni Rupa FBS UNIMED Semester II T.A 2011. 2012.

[13] E.Vahter, Looking for a Possible Framework to Teach Contemporary Art in Primary School", The International Journal of Art \& Design Education, vol. 35.pp. 51-67. 2016.

[14] W. Sanjaya, Pembelajaran dalam Implementasi Kurikulum Berbasis Kompetens. Bandung: Fajar Interpratama Offset, 2005

[15] D. Sudjana, Metode dan Teknik Pembelajaran Partisipatif. Bandung. Falah Production, 2001

[16] Palmer, "A Motivational View of Constructivist-informed Teaching," International Journal of Science Education Vol. 2, No. 15. 2005.

[17] Olson \& Hergenhahn, Berpikir Konstruktivisme: Alih Bahasa Triwibowo. [Online] Available at: http://www.blogspot.com. 2010.

[18] Departemen Pendidikan nasional, Pedoman Implementasi Kurikulum 2013. Jakarta. 2016

[19] Suryadi, "Ilustrasi yang Ilustratif,”Jurnal Dimensi. Vol 6, No 1. Hl.87100. 2008.

[20] H. Kathryn, L. Gary, Anderson, The Action Research Dissertation: A Guide for Students and Faculty. Sage Publication. 2005.

[21] R. Candrastuti, "Peran Gambar Ilustrasi dalam Cerita Pendek: Stud Kasus Cerpen Harian Kompas Minggu,” Jurnal Dimensi, vol.12, 2015.

[22] S. Aesijah, " latar Belakang Penciptaan Seni,"Jurnal Pengetahuan dan Pemikiran, vol.1.pp.63-73. 2000.

[23] B.I. Majid. "Refleksi Diri Sebagai Inspirasi karya lukis," Jurnal of Visual Arts, “"vol. 1.pp. 1-10. 2016.

[24] B.R. Hergenhahn, Olson, H. Matthew, Theories Of Learning (Teori Belajar) Hamline University, (Terjemahan) Cetakan ke 1. Kencana Prenada Media Group. 2010.

[25] B. Joyce, Models of Teaching (Model-Model Pembelajaran) Edisi Kedelapan, Jogyakarta: Pustaka Pelajar, 2009

[26] Rektor UPI, Kurikulum Universitas Pendidikan Indonesia, UPI Press.Bandung. 2019. 